\title{
Influence of Political Interests on Management of Resource Access in Awoja Watershed
}

\author{
Charles Aben $^{1}$, John James Okiror ${ }^{1}$, Jacob Godfrey Agea ${ }^{1}$, Esbern Friis Hansen ${ }^{2}$ \\ ${ }^{1}$ Department of Extension and Innovation Studies, College of Agricultural and Environmental Sciences, Makerere University, Kampala, \\ Uganda \\ ${ }^{2}$ Danish Institute for International Studies, Copenhagen, Denmark
}

Email address:

charlesaben@gmail.com(C.Aben),jokiror2010@gmail.com (J. J. Okiror),jgagea@gmail.com(J. G. Agea), efh@diis.dk(E. F. Hansen)

\section{To cite this article:}

Charles Aben, John James Okiror, Jacob Godfrey Agea, Esbern Friis Hansen. Influence of Political Interests on Management of Resource Access in Awoja Watershed. International Journal of Environmental Protection and Policy. Vol. 6, No. 5, 2018, pp. 85-96.

doi: $10.11648 /$ j.ijepp.20180605.11

Received: August 28, 2018; Accepted: November 6, 2018; Published: December 24, 2018

\begin{abstract}
This study sought to determine the extent to which local political interests under decentralization influence watershed management. The study was carried out in Soroti, Katakwi and Amuria districts in Eastern Uganda where local governance of watershed resources is being challenged by floods, draughts and mobility of communities. A cross sectional study design using both qualitative and quantitative data collection methods was employed. Factor Analysis and a Logistics Regression Model were used to analyze household survey data gathered from 180 randomly selected households; to determine influence of political factor variables on watershed management. Focus Group Discussions and key informants' interviews were also used to generate qualitative data with the purpose of explaining the relationships among variables and to analyze the extent to which various factors influenced watershed management. From the correlation results the factors that were significantly correlated to watershed management were: Community involvement in implementation was significantly correlated to watershed management $(r=0.289, \mathrm{P}<0.01)$, political interests in decisions $\mathrm{r}=0.187, \mathrm{P}<0.05)$, Reasons for punishment of offenders $(\mathrm{r}=0.55, \mathrm{P}, 0.001$. Results from the logit regression showed that dissatisfaction with regulations had an increasing influence on watershed management by $90.8 \%(\mathrm{OR}=1.908, \mathrm{P}<0.05)$. This means that management systems were highly affected by dissatisfaction of communities with rules and regulations. Similarly, community involvement in implementation of rules and regulations significantly influenced watershed management by 3 fold $(\mathrm{OR}=3.436537, \mathrm{P}<0.05)$. From the focus group discussions and KII interviews the study found that involving communities in policy implementation had led to compromises between communities and watershed governance institutions, which were perceived to have undermined the effective control of access and management of watershed resource use. The study concludes that some political interest factors and divergent activities of local institutions and actors in the watershed constrained the very processes that they should support thereby escalating degradation in Awoja.
\end{abstract}

Keywords: Political Interests, Watershed Management, Climate Change

\section{Introduction}

The natural resource management and public policy recommends the inclusion of stakeholders and their interests in decision-making and planning processes, suggesting that stakeholder inclusion contributes to, or increases the likelihood of, better decision-making, increased social learning, and community support for project outcomes [1]. However, the relationship between political interests and natural resource degradation is still not very apparent. Politics are found in the practices and mechanisms through which resources are accessed and utilized between social groups in a variety of arenas and at multiple scales. Thus, nature conservation must be understood as a political project in the context of a neoliberal accumulation regime [2].

There is growing global recognition of the urgent need to identify and implement strategies that make natural resource systems more resilient in the face of increasing climate 
variability [3]. Nowhere is this more evident than in SubSaharan Africa because the majority of Africans' livelihoods and agricultural systems rely on rain fed farming yet Africa is one of the world's regions most vulnerable to climate change. Community participation in watershed management is an important strategy of government for making watershed programs successful [4]. While recent climate change pressures have been instrumental in fostering environmental change, the roles of human and ecological relations remain significant and their manifestation exhibits a political interplay [5]. Power issues, inequalities, and conflicts are present within social-ecological environments ${ }^{3}$. This implies that land degradation in a changing climate requires politicaleconomic and ecological explanations.

Generally to address causes of degradation, natural resource management policy demands the inclusion of stakeholders and their interests in decision-making and planning processes. This suggests that stakeholder inclusion contributes to, or increases the likelihood of, better decisionmaking, increased social learning, and community support for natural resource management outcomes [6]. Consequently, stakeholder engagement has come to enjoy significant cachet as a sort of "best practice" for planning and decision-making, primarily because it is believed to be both more effective and democratic than top-down, managerialist approaches [7]. It is believed that participation of local beneficiaries in natural resource policy is important in planning, implementation and maintenance of watershed development projects. However, there is a need to know the level of institutional and community participation and influence on effective management and protection of watershed resources.

This study uses Political Ecology framework to bring on board issues of land degradation. Political ecology provides an explanation for natural resource exploitation, environmental management, forest and agricultural transformations. The framework provides an interdisciplinary approach for addressing social and environmental change. Inclusion of political interests in the analysis of resource use is basically a move to understand human-environment relationships with a view of improving social and environmental outcomes [8].

In Africa and other predominantly agrarian regions, there is particular interest in identifying political strategies to encourage farmers to adopt practices and technologies that enable more resilient, sustainable and productive natural resource management, while at the same time identifying system-wide collective action to promote a wide range of risk management activities and coping strategies [9]. However, while developing processes where facilitators, and stakeholder's co-own elements of the project encourages all groups to think about ways to operationalize empowerment, trust, and equity in watershed management, not all natural resource management contexts require the integration of local and scientific knowledge. Given the range of stakeholder engagement contexts and objects, many efforts may engage individual stakeholder groups for purposes other than knowledge integration [10].

In watershed management the stakeholders may be so diverse, including property owners and resource users, community based organizations, government officials and politicians, NGOs and parastatal organizations, research and development institutions including the academia, and the business sectors among others. These all come from different levels from the paddock to small catchments or villages, subcatchments, regional catchments, state and federal or national levels. Diversity in stakeholders gives rise to conflicting motivations and aspirations; if left unattended, such conflicts can border on hostilities [11].

In Eastern Uganda, watershed ecosystems are not receiving adequate protection through existing land use planning, watershed management, and decision-making processes. In Awoja watershed some of the key problems sited include edaphic and human factors coupled with poor governance [12]. Further management efforts have not taken recognition of the multiple, interacting institutional frameworks and partners' influence on the vitality of watershed ecosystems [13]. This is resulting in impacts on both the biophysical health of watersheds and related socioeconomic values.

This study brings on board the political forces at work in the management of Awoja Watershed in Eastern Uganda where the efficacy of institutional initiatives in dealing with climate change and other risks appear to be contingent on several local institutional factors. The study explores the exercise of power and seeks to find the link between the various political factor variables and the extent to which they influence management decisions in the watershed.

\section{Method}

\subsection{The Study Area}

The study covered the districts of Soroti, Katakwi and Amuria within the Awoja wetland system. From these districts the sub counties of Magoro, Wera and Gweri most adjacent to the wetland system were purposively selected due to their exposure to draughts and floods. The total area of the basin pertinent to the watershed stands at $10,281 \mathrm{~km} 2$. The population of Wera in Amuria is 23,930 while Magoro in Katakwi 18,564 and Gweri Sub County is 48,513 people. The sub-region experiences bi-modal type of rainfall and crop production is by far rain-fed. The average rainfall is $1,200 \mathrm{~mm}$ per annum.

\subsection{Research Design}

A cross sectional survey research design and used both qualitative and quantitative approaches to allow triangulation in data collection and data analysis [14]. The use of both qualitative and quantitative techniques enabled generation of information on watershed management and the complex interrelationships between actors and their institutions at multiple levels. 


\subsection{Sample Selection}

One sub county was selected purposively ensuring that at least a sub county near the Awoja wetland has been selected from each of the 3 districts of Soroti, Katakwi and Amuria. Systematic Random Sampling (involving randomly selecting the first household at random with the subsequent households selected at an interval) was used to select a total of 180 household respondents. Up to 32 household respondents were selected in Omugenya, Village while 28 were selected in Omusia village in Gweri Sub County. In Magoro Sub County, Angisa Parish was selected and two villages; Apopong village was selected from which 31 households were selected. The other village; Angaro was also selected and 29 households were selected to participate in the study. In Amuria; Wera Sub County was selected from which two villages were selected in Wera Parish. These villages are Morungatuny from which 30 households were selected and Okile Villages where 30 households were selected. This made a total of 180 households that participated in the study. One Focus Group Discussion was each village comprising between 8-12. A Focus Group Discussion should involve members ranging from 6-12 for adequate response [15]. In total 6 focus group discussions were conducted for the study.

For key informant interviews snowballing technique was used where initial informants were used to nominate others through their social networks, other participants who could potentially contribute to the study were used to select the respondents and included local government leaders, NGO staff involved in climate change adaptation activists, and community leaders including cultural institutions [16]. Data from the interviews and focus group discussions (FGDs) were used to analyze community dynamics and provide an understanding of underlying issues in watershed management. Questions in focus groups were designed to reinforce some of the responses that emanated from the questionnaire or from personal observations.

\subsection{Data Collection}

Household survey questionnaire was used employed to gather quantitative data used to determine the local political factor variables influencing management decisions in the watershed. Document review involving a comprehensive literature review was conducted to capture information on legal, policy, administrative and implementation frameworks related to natural resource management at local government levels. It also reviewed relevant information and other studies from various sources. Some of the documents reviewed included: The Decentralization Policy, Wetlands Protection Act, development plans, annual budgets, monitoring and evaluation reports and many others [16]. Key informant interview was used to collect primary data that was used to evaluate the policy development processes, including the principles in the framing of policies governing natural resource management and to measure variations between policy frameworks and real governance practices of natural resource management in a changing climate. The study also conducted face-to-face/one-on-one interviews with civic leaders and leaders of NGOs involved in adaptation to climate change programs in the three districts were carried out. Semi structured questionnaires were used due to their flexibility to probe for details. Inputs from people at various levels of governance, local government technical (Sub county: Senior Assistant Secretaries, Parish Chiefs, Environment Focal Point Officers, and political wing (LC III Chairperson, Councilors, and members of the Sub-county executive). Information was also collected from CSOs and extra local institutions (members of Parish Development Committees and members of Disaster Risk Management Committees). Focus group discussions was employed to gather community perceptions on local participation in resource management.

\subsection{Data Analysis and Interpretation}

Qualitative data was analyzed through an iterative process where data collected was grouped to make inferences. This allowed a link where analysis of data was not a distinct stage of the process of research but built in from the research design and pre fieldwork phase. Analysis was also based on data themes generated from the qualitative interviews, while additional data was collected based on gaps realized during the analysis. Reflexivity was employed in order to inwardly identify meanings of relationships emerging from the data collected in the field. For quantitative analysis, data entry template was prepared using epidata (version 3.2) from the revised questionnaire following the pilot study. Data from the respondents were entered in epidata, and exported to Stata software (version 13.1) for cleaning and analysis. The data was then explored for normality by using KolmogorowSmirnov normality test and were normally distributed ( $>0.05)$, to decide on the probable statistics if relevant assumptions were met. Since the assumptions for parametric tests were met, the study utilized both descriptive and inferential statistics amenable to parametric analysis. Whereas descriptive statistics involved the use of central tendency (means), frequencies, proportions, standard deviation and variance; the inferential tests employed the use of Pearson correlation to test the relationships between the main study variables and the nature thereof; as well as to test the hypotheses.

Logistic regression analysis was performed to establish the influence of the independent variables (local political processes,) on the dependent variable (management of the water shed). The study employed factor analysis to identify the independent factors explaining relationships amongst the main variables; factor analysis was performed to establish the strength of the different factors in the model. A factor analysis was carried out to provide/reduce a large number of observed variables to smaller number of factors and to provide a regression equation for an underlying process by using observed variables [17]. The factor analysis was performed for a set of parameters that described both the dependent variable (management of the watershed) and the 
independent variables (local political processes, social issues, economic interests, and climate change). The correlation matrix of variables was used to obtain Eigen values. In order to facilitate interpretation of factor loadings $\left(l_{\mathrm{ik}}\right)$, VARIMAX rotation was used. Factor coefficients $\left(c_{i k}\right)$ were used to obtain factor scores for selected factor [17]. The factor number equals the number of Eigen values of the population correlation matrix that are greater than unity. Therefore, the factors with Eigen values $>1$ was employed in regression analysis [18]. Average values for Eigen values $>1$ for each independent factor were obtained and regressed against the dependent variable.

\section{Results}

\subsection{Local Political Interest Factors in Watershed Management in Awoja}

Twenty-one questions relating to local political processes were factor analyzed using principal component analysis with Varimax (orthogonal) rotation. The analysis yielded seven factors explaining a total of $69.96 \%$ of the variance for the entire set of variables (Table 1). Factor one was labeled "dissatisfaction with regulations" due to the high loadings by the following items: what happens when communities are not satisfied with regulations; who is in charge of implementing rules and how conflicts over land have affected politics in the area. This first factor explained $13.37 \%$ of the variance. The second factor derived was labeled "community involvement in implementation of rules". This factor was labeled as such due to the high loadings by the following factors: persons or institutions responsible to allocate wetlands for use; and persons/institutions responsible to allocate forests for use; the variance explained by this factor was $24.28 \%$. The third factor obtained due to the high loadings of the variables was "Implementation of current land use policy". This entailed; how those who break regulations are treated; how involvement of the community and local institutions have changed ways rules are being implemented; and what local governments needs to do to improve policy implementation. The fourth factor was labeled "political influence on wetland use" and was based on the following factor loadings; how are rules for environment protection developed and how to assess the current land use policy. Items loaded to factor five relate to reasons cited for punishment of offenders and this was labeled; "relevance of reasons for punishment of offenders". Factor six derived from the following factor loadings; benefits of the watershed to the local government; who has the power to allocate communal land for use and how stakeholders are involved in the allocation of resources in the watershed was labeled "local government conflict of Interests" and factor seven defined by high loadings of the factors; ways offenders are punished was labeled "punishment of offenders" which explained $8.9 \%$ of the variance of the variables.

The communalities of the variables included are rather low and this indicates that the variables chosen for this analysis are only weakly related with each other. However the KaiserMeyer Olkin (KMO) and Bartlett's Test of Sphericity both indicate that the set of variables are at least adequately related for factor analysis. Substantively, this means that we identified seven clear patterns of response among respondents. These seven tendencies are independent of one another (i.e. they are not correlated). Details are presented in table 1 below:

Table 1. Factor Analysis of the Political Process Variables.

\begin{tabular}{|c|c|c|c|c|c|c|c|c|}
\hline Variable & Factor 1 & Factor 2 & Factor 3 & Factor 4 & Factor 5 & Factor 6 & Factor 7 & Uniqueness \\
\hline Rules & -0.0874 & 0.0025 & -0.0616 & 0.7570 & 0.0808 & -0.0690 & -0.0047 & 0.4043 \\
\hline Charge & 0.6253 & 0.3630 & 0.1076 & -0.3658 & -0.0269 & -0.1141 & 0.0282 & 0.3173 \\
\hline Access 1 & -0.1047 & 0.1887 & -0.3911 & -0.6564 & -0.2497 & 0.1320 & -0.1710 & 0.2605 \\
\hline Powers1 & 0.2965 & 0.7827 & 0.0810 & -0.0475 & -0.2388 & 0.1757 & 0.1663 & 0.1751 \\
\hline Powers2 & -0.2767 & 0.8790 & 0.0840 & -0.0415 & 0.1553 & -0.1058 & 0.0335 & 0.1056 \\
\hline Powers3 & -0.2002 & 0.2250 & -0.0049 & -0.1407 & 0.3110 & 0.5254 & -0.0991 & 0.5069 \\
\hline Effective & -0.4673 & -0.2860 & 0.3522 & -0.0810 & -0.0815 & -0.0175 & 0.2195 & 0.5140 \\
\hline Ntsatisf & 0.4435 & -0.4055 & -0.0338 & 0.3971 & 0.0777 & -0.0346 & -0.4241 & 0.2930 \\
\hline Treat & 0.1462 & 0.1030 & 0.8042 & 0.0532 & 0.2164 & 0.0464 & 0.0212 & 0.2690 \\
\hline Purnish & 0.0628 & -0.0512 & 0.1105 & 0.2377 & 0.0136 & 0.0994 & 0.8373 & 0.2872 \\
\hline Reasonpu & -0.1511 & -0.1566 & 0.3602 & -0.0580 & 0.7916 & 0.7714 & 0.0205 & 0.2239 \\
\hline Demacate & -0.8162 & 0.0521 & 0.0433 & -0.1673 & 0.0064 & 0.0886 & -0.0527 & 0.2907 \\
\hline Decision & -0.1947 & -0.0832 & 0.1637 & 0.0207 & 0.0944 & -0.7632 & -0.1834 & 0.3029 \\
\hline Benefit1 & 0.1885 & 0.0792 & -0.1164 & 0.0307 & -0.1291 & 0.1185 & 0.0315 & 0.2119 \\
\hline Conflict & 0.7985 & -0.1445 & 0.2943 & -0.2031 & 0.0785 & 0.0956 & 0.1026 & 0.1878 \\
\hline Resolvin & -0.1458 & -0.4647 & -0.3425 & 0.3306 & 0.1610 & 0.3264 & -0.0401 & 0.4022 \\
\hline Involvem & 0.3986 & -0.0436 & 0.3496 & 0.3888 & -0.4843 & 0.1002 & -0.0801 & 0.3149 \\
\hline Stakehold & 0.0386 & -0.0289 & 0.0342 & -0.0291 & 0.6932 & -0.1077 & -0.4487 & 0.3022 \\
\hline Assess 1 & -0.2882 & -0.0434 & -0.0960 & 0.5634 & -0.4624 & 0.0037 & -0.2997 & 0.2847 \\
\hline Improve1 & 0.1311 & 0.3208 & 0.6720 & 0.0421 & -0.2332 & 0.1520 & -0.1845 & 0.3149 \\
\hline
\end{tabular}




\begin{tabular}{lllllllll}
\hline Variable & Factor 1 & Factor 2 & Factor 3 & Factor 4 & Factor 5 & Factor 6 & Factor 7 & Uniqueness \\
\hline Charge & 0.6253 & 0.3630 & 0.1076 & -0.3658 & -0.0269 & -0.1141 & 0.0282 & 0.3173 \\
Eigen values & 3.2562 & 2.8577 & 2.2038 & 1.9548 & 1.7830 & 1.4105 & 1.2249 \\
Variance & 2.8072 & 2.29161 & 2.08291 & 2.04474 & 2.03621 & 1.72889 & 1.69924 \\
Proportion of variance & 0.1337 & 0.1091 & 0.0992 & 0.0974 & 0.0970 & 0.0823 & 0.0809 \\
Cumulative & 0.1337 & 0.2428 & 0.3420 & 0.4394 & 0.5363 & 0.6186 & 0.6996 \\
\hline
\end{tabular}

\subsection{The Relationships Between Political Interests and Watershed Management}

The relationships between political process and management of the watershed are shown in Table 2. From the correlation results, there is a significant relationship between the political process and management of the watershed $(\mathrm{r}=$ $0.483 \mathrm{P}<0.001)$. The results however indicated a negative relationship between climate change and watershed management $(\mathrm{r}=-0.098, \mathrm{P}>0.05)$ meaning that increasing climate change reduces the effective resource management. The relationship between climate change factor and political interests was positive and significant $(\mathrm{r}=0.377, \mathrm{P}<0.001)$. This means that climate change factors influence political processes in the watershed. Thus political players have gotten more involved in adaptation processes with increasing frequency of climate change trends.

Table 2. The correlation between political process and management of the watershed.

\begin{tabular}{llll}
\hline Variable & & $\mathbf{1}$ & $\mathbf{3}$ \\
\hline Watershed management (1) & Pearson correlation & 1.000 & \\
& Significance (2-tails) & & 1.000 \\
Political process (2) & Pearson correlation & $0.483 * * *$ & \\
& Significance (2-tails) & 0.000 & $0.377^{* * *}$ \\
Climate change factors (3) & Pearson correlation & -0.098 & 0.000 \\
\hline
\end{tabular}

*** implies sig at $0.001, * *$ implies sig at $0.01,, *$ implies sig at 0.05

Table 3 shows the relationships between different political interest factors and management of the watershed. The results show that involvement of the community, political influence on wetland use, relevance of reasons for punishment of offenders and local government conflicts of interests had significant correlation with watershed management $(\mathrm{P} \leq 0.05)$. The results also show that though not significant, punishment of offenders and the implementation of current land use policies are negatively correlated to watershed management. This depicts some level of community resentment in the way the practices are being executed.

Table 3. Correlation between watershed management and the individual local political interest factors.

\begin{tabular}{|c|c|c|c|}
\hline Local political Interest Factors & Mean & $\mathbf{r}$ & Sig \\
\hline PP1-Dissatisfaction with regulations & 2.26 & 0.163 & 0.082 \\
\hline PP2- community involvement in implementation & 2.07 & $0.289 * *$ & 0.002 \\
\hline PP4-Political influence on wetland use & 4.66 & $0.187 *$ & 0.044 \\
\hline PP5-Relevance of reasons for punishment of offenders & 3.71 & $0.555^{* * *}$ & 0.000 \\
\hline PP6-Local Government Conflict of Interests & 3.70 & $0.307 * * *$ & 0.001 \\
\hline PP7-Purnishments for offenders & 4.41 & -0.121 & 0.197 \\
\hline
\end{tabular}

Factors obtained after data reduction, factor analysis factor loadings

*** implies sig at $0.001, * *$ implies sig at $0.01, *$ implies sig at 0.05

The consequence of community involvement in implementation and watershed management is manifested in the way they change the implementation of rules. The relationship was significant at $(\mathrm{r}=0.289, \mathrm{P}<0.01)$. This means that the more the involvement of the community, the greater is its impact on management. Respondents site enforcement of rules and regulations and sensitization of communities as some of the major contributions of the Disaster Reduction and Management Committees (DRMCs) have made to management of the watershed.

Whereas community involvement through the disaster reduction and management committees (DRMCs) is, interactions with key informants however, showed that at times DRMC shave had negative effects on watershed management. For example, the study revealed that some of the rules stopping the community from using the resources have been relaxed because the community representatives in the DRMC successfully lobbied for them to be relaxed. This was particularly identified in Angisa parish in Katakwi district where though it was a government policy to demarcate land for whatever reason, the community members refused to vacate some of the land demarcated for wildlife 
reserve. Since the remaining land was not adequate for the communities, the DRMC lobbied government to relax wetlands rules and to provide the people of Angisa parish part of the Angisa wetlands for cultivation even when under the environmental protection law, wetlands are no go areas for cultivation.

The other factor that was found to be significant was political involvement indecision making for wetland use $(\mathrm{r}=0.187, \mathrm{P}<0.05)$. The study found a number of political forces at play in the decision-making processes about access and use of protected resources. For example in Amuria, climate change management was integrated in the political agenda in the district with the district council supporting measures for environmental conservation by creating awareness, developing an ordinance at district level and bylaws in each sub county. However, some political influences on management had negative implications. This included actions of politicians aimed at changing rules to favor the community in anticipation of political gains.

One other factor that was significantly related to management of the watershed was the reasons for the punishment of offenders $(\mathrm{r}=0.555, \mathrm{P}<0.001)$. This meant that the more relevant the reason for punishment of offenders, the greater was the likelihood that it would enhance sustainable management of the watershed. The respondents however noted that despite offenders getting punished for illegal access to protected areas, encroachment still continued unabated. This depicts that the offenders did not appreciate some of the reasons for punishment.

Conflict of interests of local governments arising from benefits of resources to local governments was also found to be a factor significantly correlated to watershed management $(\mathrm{r}=0.307, \mathrm{P} \leq 0.001)$. The community perception was that increasing conflict of interest was increasingly influencing decisions on watershed management. It was observed in the qualitative results that because of the interests by local government officials to use the protected resources by themselves and the need by the elected politicians to protect their votes, the implementation of most rules and regulations had been relaxed.

\subsection{Perception Respondents on the Roles of Different Political Process FActors}

Different respondents gave varying opinions on the involvement of the community in implementation of rules. The findings show that most female respondents (44\%) felt that rules can be changed to meet the community demands while most male respondents $(41.8 \%)$ feel that nothing has been done (Table 4)
On dissatisfaction with regulations close to equal proportions of the male and female respondents $(38 \%$ male and $38.3 \%$ female) felt that the community negotiates for changes in rules and regulations. Up to $30 \%$ of the female respondents feel that people defy rules and continue with prohibited activities while $20 \%$ feel that they have no voice to change any rules and regulations (Table 4). On implementation of current land use policy the findings show that close to equal proportion of the respondents $(45.5 \%)$ and (44.3)\% respectively felt that the land use policy is good and effective and that the land use policy was not good and does not favor the common man (table 4). However most female respondents $(47.5 \%)$ felt that the current land use policy is good and effective while most male respondents (46.2\%) felt that land use policy was not good and does not favor the common man (table 4).

The findings from the survey reveal that most male respondents $(52.8 \%)$ and female respondents (41.8\%) felt that reasons for punishment of offenders was not being fairly carried out since those offenders who had connections with local leaders either as friends/relative to the leaders were not punished. Offenders who broke rules and regulations faced different punishments. The findings of the survey show that equal proportions of the male and female respondents $(46.7 \%)$ state that offenders are fined and charged. $16.7 \%$ of the male respondents pointed that some of the offenders are asked to apologize and are released, while $23.3 \%$ of the female respondents stated that some of the offenders were imprisoned. About $30.9 \%$ female and $15.7 \%$ male respondents felt that the reasons for punishment of some offenders were not clear due to lack of transparency among the enforcement agents and leaders.

The watershed was found to be a significant resource to the local government institution. The findings reveal that local government was highly interested in the resources due to revenue earned from it in the form of taxes as expressed by $52.8 \%$ of the respondents. More than half of the male respondents $(55.8 \%)$ and $46.7 \%$ of the female respondents cited revenue earned from taxes as a factor for local governments interest in resources. Further, 28.3\% female and $18.3 \%$ male respondents cite money earned from fines as a factor for local governments interest in the watershed resources (table 4). Another reason for local government interest is that they use the watershed management to collect data and information to meet their reporting obligations to the higher authorities. Equal proportions of the male and female respondents (21\% male and $20 \%$ female) cite information as a factor for local government interest in the watershed resource.

Table 4. Perceptions on implementation of rules and regulations in watershed management.

\begin{tabular}{|c|c|c|c|}
\hline Local political interest factors & Male & Female & Total \\
\hline \multicolumn{4}{|l|}{ Perception on involvement of community in implementation } \\
\hline Rules can be changed to meet community demands & $29(26.4)$ & $26(44.1)$ & $55(32.5)$ \\
\hline Nothing has changed & $46(41.8)$ & $20(33.9)$ & $66(39.1)$ \\
\hline Perception on Dissatisfaction with regulations & & & \\
\hline
\end{tabular}




\begin{tabular}{|c|c|c|c|}
\hline Local political interest factors & Male & Female & Total \\
\hline Defy and continue with prohibited activities & $29(24.6)$ & $18(30.0)$ & $47(26.4)$ \\
\hline Negotiate for changes in rules and regulations & $46(39.0)$ & $23(38.3)$ & $69(38.8)$ \\
\hline They have no voice to change anything & $24(20.3)$ & $7(11.7)$ & $31(17.4)$ \\
\hline Lobby politicians and local leaders & $19(16.1)$ & $12(20.0)$ & $31(17.4)$ \\
\hline \multicolumn{4}{|l|}{ Perception on implementation of current land use policy } \\
\hline The land use policy is good and effective & $52(44.4)$ & $28(47.5)$ & $80(45.5)$ \\
\hline Not good and does not favor the common man & $54(46.2)$ & $24(40.7)$ & $78(44.3)$ \\
\hline The policy is weak, discriminative and contradicting & $11(9.4)$ & $7(11.9)$ & $18(10.2)$ \\
\hline \multicolumn{4}{|l|}{ Perception on how decisions on wetland use are influenced } \\
\hline Community holds meetings to determine decision to use wetlands & $5(4.3)$ & $8(13.6)$ & $13(7.4)$ \\
\hline Decisions are influenced due to rice prices & $17(14.5)$ & $3(5.1)$ & 20(11.4) \\
\hline Decisions are mainly influenced by NEMA & $6(5.1)$ & $3(5.1)$ & $9(5.1)$ \\
\hline Decisions influenced when conflicts in wetland use escalate & $9(7.7)$ & $8(13.6)$ & $17(9.7)$ \\
\hline Influenced by high poverty levels & $59(50.4)$ & $20(33.9)$ & $79(44.9)$ \\
\hline Influenced by political leaders due to political pressure & $4(3.4)$ & $5(8.5)$ & $9(5.1)$ \\
\hline When people go beyond the buffer zone and are not punished & $2(1.7)$ & $7(11.9)$ & $9(5.1)$ \\
\hline When there is drought and the need for food & $15(12.8)$ & $5(8.5)$ & 20(11.4) \\
\hline \multicolumn{4}{|l|}{ Perception on relevance of Reasons for punishment of offenders } \\
\hline Admission of mistake & $3(2.8)$ & $1(1.8)$ & $4(2.5)$ \\
\hline Bribery of leaders/institutions & $17(15.7)$ & $17(30.9)$ & $34(20.9)$ \\
\hline Cases not reported & $19(17.6)$ & $7(12.7)$ & $26(15.9)$ \\
\hline Friends/Relative connection with leaders & $57(52.8)$ & $23(41.8)$ & $80(49.1)$ \\
\hline Increased enmity & $2(1.8)$ & $2(3.6)$ & $4(2.5)$ \\
\hline Influence by politicians & $2(1.8)$ & $0(0.0)$ & $2(1.2)$ \\
\hline Lack of evidence & $1(0.9)$ & $0(0.0)$ & $1(0.6)$ \\
\hline Relaxed regulations & $7(6.5)$ & $5(9.1)$ & $12(7.4)$ \\
\hline \multicolumn{4}{|l|}{ Perception on Local government interests in resources } \\
\hline Income from tourism & $2(1.7)$ & $0(0.0)$ & $2(1.1)$ \\
\hline More money from fines & $22(18.3)$ & $17(28.3)$ & $39(21.7)$ \\
\hline Provide a community service & $4(3.3)$ & $3(5.0)$ & $7(3.9)$ \\
\hline Revenue from Taxes & $67(55.8)$ & $28(46.7)$ & $95(52.8)$ \\
\hline Source of information for implementing government programs & $25(20.8)$ & $12(20.0)$ & $37(20.6)$ \\
\hline \multicolumn{4}{|l|}{ Perception on mode of Punishment of offenders } \\
\hline Asked to apologies & $20(16.7)$ & $3(5.0)$ & $23(12.8)$ \\
\hline Asked to plant more than what is cut & $10(8.3)$ & $0(0.0)$ & $10(5.6)$ \\
\hline Confiscation of property & $0(0.0)$ & $1(1.7)$ & $1(0.6)$ \\
\hline Engaged in community service & $18(15.0)$ & $10(16.7)$ & $28(15.7)$ \\
\hline Fined and charged & $56(46.7)$ & $28(46.7)$ & $84(46.7)$ \\
\hline Imprisonment & $9(7.5)$ & $14(23.3)$ & $23(12.8)$ \\
\hline None & $7(5.8)$ & $4(6.7)$ & $11(6.1)$ \\
\hline
\end{tabular}

\subsection{The Influence of Local Political Interest Factors on Watershed Management}

Given the above factors mentioned by respondents, local people have variable perceptions on the roles of local governance institutions in regard to watershed management. Therefore, to determine the extent to which political factor influence management of the watershed a Logistic Regression Analysis was performed. The role of the logistic Regression model was to show the strength and direction of influence of different factors generated in the factor analysis, represented by Odds Ratios (OR). Odds ratios less than had decreasing influence on watershed management while ratios more than 1 had increasing influence on watershed management decisions.

The results of the logistic regression analysis (Table 5) show that political interest factors represented by P1, P2, P3, P4, P6 and P7 had an increasing influence on watershed management while factor P5 had decreasing influence on watershed management. 
Table 5. The logistic regression model of the political factors and watershed management.

\begin{tabular}{llllll}
\hline $\mathbf{Y}$ & Odds Ratio & Std. Err. & $\mathbf{P}>\mathbf{z}$ & [95\% Conf. & Interval] \\
\hline PP1 & 1.908414 & .5882648 & 0.036 & 1.043017 & 3.491836 \\
PP2 & 3.436537 & 1.109646 & 0.000 & 1.825034 & 6.470994 \\
PP3 & 1.176567 & .3689127 & 0.604 & .6363881 & 2.175259 \\
PP4 & 1.190405 & .3485458 & 0.552 & .6706039 & 2.113115 \\
PP5 & .6455376 & .1667355 & 0.090 & .3891036 & 1.070971 \\
PP6 & 1.744876 & .5784852 & 0.093 & .9110929 & 3.341693 \\
PP7 & 1.470603 & .4089687 & 0.165 & .8526673 & 2.536361 \\
\hline
\end{tabular}

Key: PP1-Disatisfaction with regulations, PP2- Community involvement in implementation, PP3- Implementation of current land use policy, PP4-Political influence on wetland use, PP5, Relevance of reasons for punishment of offenders, PP6-Local Government Conflict of Interests PP7-Purnishments for offenders

From table 5, dissatisfaction with regulations had an increasing influence on watershed management by $90.8 \%$ $(\mathrm{OR}=1.908, \mathrm{P}<0.05)$. This means that the more people were dissatisfied with rules and regulations, the more pressure they would exert on the management system. Similarly, community involvement through their (DRMC) in implementation of rules and regulations significantly increased influence on watershed management by 3 fold $(\mathrm{OR}=3.436537, \mathrm{P}<0.05)$. This shows the extent to which DRMCs were instrumental in influencing management of resources in the watershed. However, although current land use policy, political influence on wetland use, local government conflicts of interests and punishment of offenders also had an increasing influence on watershed management, the influence was not significant. For example, respondents perceive that although current land use policy is in place, it was not being effectively implemented and thus; political influence on watershed management is not adequately resulting into changes in the watershed management. The results further show that the relevance of rules and regulations had a decreasing influence on watershed management by $36 \%$. This means that if the offenders do not appreciate the reasons for punishment, punishment will contribute less and less to watershed management.

\subsection{Implications of Political Interests for Sustainable Watershed Management}

Based on the relationships between political interests' factors and watershed management discussed and based on the qualitative results, the following analysis summarizes the implications of political interests for watershed management.

From the FGDs, the study found that when dissatisfied with rules and regulations (Factor PP1), resource users lobbied for concessions through existing power centers. This is exemplified by the negotiations that resulted in reducing the buffer zone in demarcated wetlands to 15 meters from the mandated 30 meters. This has had a negative implication on the wetlands. An analysis of perceived power centers for natural resource management as viewed by community members was as follows: i) government working together with local leaders and NGOs ii) traditional leaders working alone iii) government and NGO and iv) government working alone. Results from key informant Interviews on compliance to rules and regulations showed that community members in the watershed were not necessarily compliant to the regulations especially those that affect their livelihoods negatively. This was because the community members had learnt that the rules were not cast on stone and could be easily negotiated. In other words, environmental degradation was on the increase as a result of this practice of negotiations of rules between community members and the enforcement agencies and politicians.

From the logistic regression table 5 above, implementation of policies governing access and utilization of common policy had a positive and increasing influence on watershed management as shown by the influence of factor PP3Implementation of policies $(\mathrm{r}=1.176567, \mathrm{P}<0.01)$. Where implementation of policies is weak, interventions will contribute less to resource protection. Weak policy implementation has had negative implications on sustainability. In Amuria district inaction of government officers and local community enforcement officers are linked to conflict of interests as the officers are also illegally using the demarcated land for production of rice. There are therefore mixed feelings about access after demarcation in Amuria as one woman remarked:

"We are very happy today because everybody now has access to the wetland. In the past we could not access the wetland for grass, water, fish or even clay. Those near the wetland could not allow other people to enter the wetland without their permission but now the story is different. There is complete equality in access" (Field Interviews, $8^{\text {th }}$ May 2016).

This statement shows that inadequate regulation had promoted irrational use of common pool resources instead of promoting conservation. It was reported that government officials only verbally informed community members about restriction son watershed resources without enforcing the associated rules. This has led to competition for the resources as one respondent argued:

"...if I see other people have cultivated where I used to cultivate before demarcation, should I keep watching? I just go to the middle of the swamp also and struggle till we are separated by someone else from outside" (Field interview, $8^{\text {th }}$ May 2016).

The management of access to the wetlands and forests in 
Angisa in Magoro sub county in Katakwi where community land was annexed, as part of wildlife conservation was a bit different. The government had allowed the people to use part of the wetland because most of the upland had been demarcated for wildlife. However, the community members refused to cultivate the wetlands because they felt if they accepted to cultivate, government would conclude that they had accepted to leave their traditional land taken by Uganda
Wild Life Authority. Therefore, the people have continued to encroach on the land demarcated for wild life conservation.

Policy implementation in Awoja watershed is summarized in the figure 1 . The figure shows the dynamics in the exercise of power in the control of access to environmental resources in the watershed.

\section{Levels of political interest Power Centers}

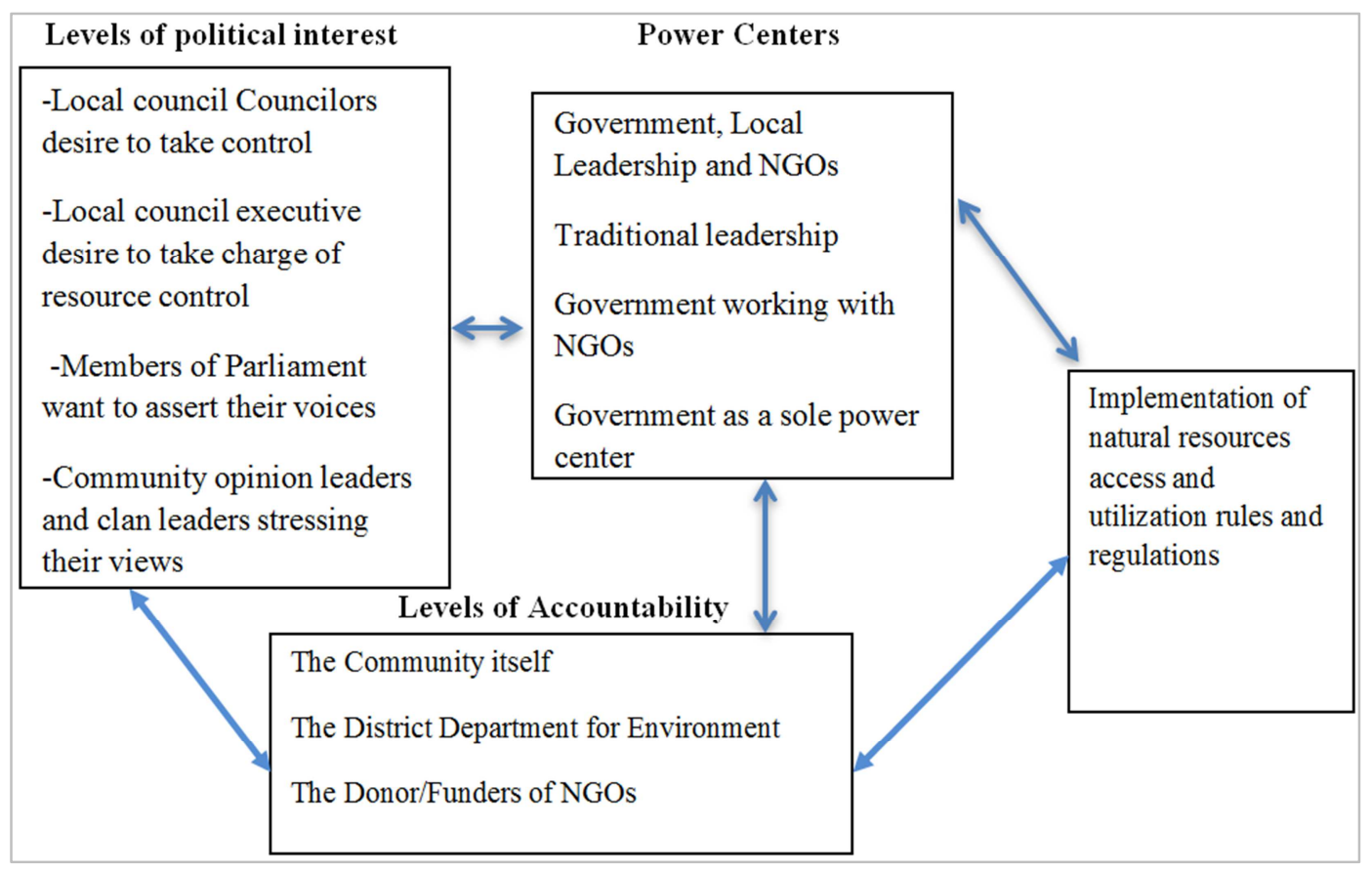

Figure 1. Power constellations in Awoja watershed (Source: Field research May 2016).

As can be seen from figure 1, there are different levels of political interests and struggles within the watershed: local councilors are interested in taking control of watershed resource control while their executives are desirous of the same control as an interest group. Members of parliament on the other hand want to assert their voices as overall policy makers while community leaders want their views stressed. The key power centers consisting of governments at local and national levels, traditional leaders and NGOs are at tension with local political interest groups. The power centers and local political interests must however provide accountability to districts local governments, the community and donors.

From the key informants interviews it was found that community members were aware of the political interest of various political groups and were using them to negotiate for concessions in the rules and negotiations in exchange for political support. From the Household survey results the majority of the community members mentioned that they can negotiate to make changes in the regulations. This was revealed by 69 (38.8\%) followed by $47(265)$ who indicated that they defy and continue with prohibited practices since their leaderships were aware of the constraints they were facing. The residents of Omugenya revealed that they had continued to use the wetlands because they had no alternatives. The chairman of Omuganya explained that one cannot stop people from using the wetland when actually the upland is dry. "We leaders must therefore act like human beings and allow people to use the wetlands for some time while we are monitoring the changes in climate". In Angisa, residents had refused to leave the land demarcated for wildlife and had continued to cultivate it. This forced the government to install a permanent police station in the area to stop residents from using the demarcated land. However, the police instead remained watching as people cultivated the land. Asked why the police was behaving that way, a police officer said;

My friend, we are also human beings. We also need food while we stay here. Instead what some of us are doing is to make sure we use these people's oxen and we also cultivate because this is a fertile land and we all need the food (Field interviews, $9^{\text {th }}$ May 2016)

Other aspects of defiance included continuing the cutting of trees particularly the Shea nuts and Tamarind trees for charcoal even when the trees had been declared as protected species.

It was also revealed that the sentences given to encroachers were too light; some of the offenders are sometimes allowed to just apologize and are left free while others are often locked up for only a few hours, 
while others were made to replant grass in degraded areas. It was however mention that some few offenders are allowed to plant more trees if the offence was cutting a tree, they could be caned, their property can be confiscated, given community services, fined and charged or even imprisoned. Respondents however perceive that the punishments were subjective and not fair.

A probe on reasons why some offenders were not given punishment showed that increasing suspicion of corruption as a main explanation for this phenomenon. It was found that at times when offenders were reported to the police in the evening in the morning they would find they have already been released. This was so annoying to the residents that many environmental cases were no longer being reported.

It was also revealed that some political leaders fail to punish the offenders because they do not want to create enmity with their own voters. It was revealed by one of the chairpersons in Amuria that people always tell leaders that whatever they did, they should always be careful and remember they would meet in the basin (A basin is a container where the ballot paper is secretly ticked from during an election?

It was further revealed by residents of Omugenya in Soroti district that some leaders could not punish offenders because the leaders themselves were also accessing the prohibited resources. Some leaders were also involved in the cultivation of rice and grazing in the wetlands. Respondents revealed, that the leaders couldn't reprimand those who break the rules because they break them together. In Angisa, residents revealed that the leaders could not stop them from using the land yet they were living with them and were aware of the existing poverty and food security stress brought about by climate change. One resident noted;

"How can they stop us from using the demarcated land yet they also need the same food that we are growing on the land?" (Field interview, $9^{\text {th }}$ May 2016)

From the above findings, it can be asserted that compromise with enforcement agencies have weakened the compliance to rules and regulations and weakened the legitimacy of resource management regime in Awoja Watershed leading to increasing unsustainable exploitation of the protected natural resources.

\subsection{Summary of Findings}

In view of the above results on the relationship between political processes and watershed management, the following qualitative model has been derived as indicated by Figure 2 that illustrates the interactions between political processes and watershed management.

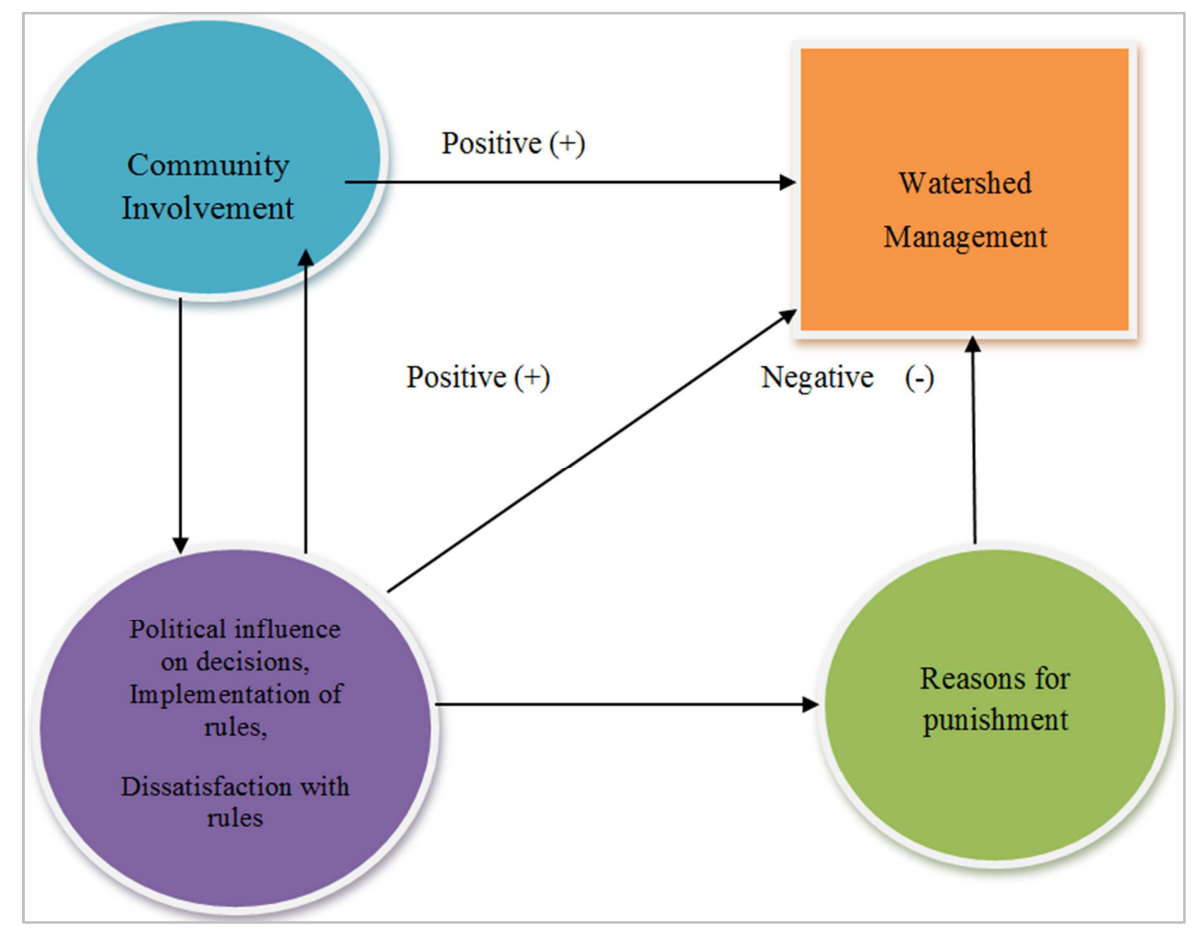

Key: (+): means increasing influence, $(-)$ means negative influence, $\rightarrow$ Means direction of influence

Figure 2. Summary of findings on political processes in Awoja watershed.

\section{Discussion}

The findings show that the way the exercise of power was being conducted by local governance institutions determined resource user groups' dissatisfaction/satisfaction to rules and regulations in the management of resources in Awoja watershed. Subjective application of rules and regulations were the main reasons for dissatisfaction. While local government play a major role in climate change policy development [19], the findings of this study show how despite the positive role played by local government 
institutions in formulation and implementation of policies, emerging political interests are a constraint to watershed management.

From the results, the multiplicity of power centers involving different configurations of Government/NGO/Traditional Leaders for management of common pool resources in Awoja watershed was evident. From the key informant interviews however it was revealed that resource user groups navigated through these power centers to circumvent the rules that they felt were not in their favor. While participation in watershed restoration is important [20], the findings from this study show that participation in watershed management can be used by community leaders to renegotiate the environmental rules. Therefore, whereas participation brought about involvement of communities in watershed management, the communities used this opportunity to navigate through the power centers and circumvent the environmental rules and regulations. Moreover, local community leaders also broke the same environmental rules as they used their positions to exploit the prohibited resources. This is in line with Sikor \& Lund [21] who noted the existence of competition over institutional authority in natural resource management.

Navigation through power centers in natural resource governance in Awoja Watershed brings to question the compliance to standards in the implementation of environmental rules and regulations. It also shows the fluid, dynamic and sometimes; ambiguous nature of institutions involved in natural resource management in the watershed. Ong'or [22] showed that institutional structures, power, rights and entitlements at multiple levels of governance was essential to adaptation. This view is in line with the finding that often strategies are shaped by institutional, cultural, and socio-economic contexts and may be undertaken by a variety of stakeholders [23]

The findings also showed the increasing influence of the community through their DRMCs in watershed management. However, use of DRMCs by the community to renegotiate environmental rules is detrimental to the environment protection. This finding is consistent with Few [24] who observed that involving a wide range of stakeholders in decision-making presents fundamental challenges for climate policy, many of which are embedded in relations of power. The question of power and participation at different levels of governance, formal and informal is an important component of watershed management. Worldwide, strong formal and informal institutional frameworks are important for the dayto-day implementation of watershed activities [25]

From a contextual standpoint, understanding the local institutional, legal and cultural constraints are important [26]. The findings of the negativities associated with the political interests of local institutions including DRMCs bring to question the extent to which local community participation in watershed management can be employed. While strengthening the top down roles of local governments in managing the watershed would be desirable, rigid hierarchical and bureaucratic structures are strong barriers to social learning in watershed resource management [27] and [28]. This calls for an understanding of the tradeoffs between the use of formal and informal institutions in watershed management and a meaningful integration. For Awoja watershed a combination of formal and informal watershed governance system is desirable. However, since the results have shown that dissatisfaction with rules and regulations as well as poor implementation of policies by local leaders fueled non-compliance leading to increased encroachment on protected watershed resources, any policy development for the watershed should focus on improving the leadership of resource management groups.

\section{Conclusion and Recommendations}

The study has shown although local institutions are supposed to safeguard natural resources through streamlining implementation of rules and regulations, the situation in Awoja was different as there was compromise on the utilization of natural resources. Local politicians manipulated rules and regulations to fit their own political interests. The local communities on realization of the power they possess in influencing leadership, have used this power to negotiate for relaxation of the rules. This has contributed to the increased degradation of the watershed.

From the study, participation of political and community leaders in environmental protection has been motivated by divergent interests. While management institutions were interested in advancing sustainable use of resources without losing political capital, the communities were interested in uninterrupted access to the natural resources by navigating through the existing power constellations in the watershed. Fear of political repercussions associated with management decisions have led to subjective management decisions and poor environmental protection. Complacency was exhibited by politicians practicing some kind of "constructive empathy" towards politically important groups where the people in power aim to be seen to be considerate to the community but with the ultimate aim of building reciprocity between the politicians and the voters.

Owing to the above, the political landscape in the watershed was characterized by compromises, negotiations and complacency of law enforcement officers to change local government rules and regulations to fit the people's interests when pressurized by a changing climate. On the other hand, compromise was also evident where degradation of the watershed is allowed to continue under the watch of leaders who fail to act because of fear of stressing their fragile relationship with community members. All these instances have affected the management of the watershed.

It is recommended that government enhance protection of watershed resources through training of local politicians, local government officers and local environmental committees on integrity and accountability to avoid subjective implementation of environmental rules and regulations. Restoration measures including diversification of the economic activities in the watershed in a way that reduces 
overdependence on the available resources is another option. There is also need to empower resource management committees to work closely with local governments to enforce compliance of all actors to set natural resource policies without unnecessary compromises.

\section{References}

[1] Knapp A (2014). Climate change and precipitation Consequences of more extreme precipitation regimes for terrestrial ecosystems, Colorado State University.

[2] Khan, M. T. and T. Lynch (2013). The genealogy of contemporary nature/forest conservation. Human Geography: a New Radical Journal 6(3): 105-120.

[3] Amaru, S., \&Chhetri, N. B. (2013). Climate adaptation: Institutional response to environmental constraints, and the need for increased flexibility, participation, and integration of approaches. Applied Geography, 39, 128-139.

[4] Bagdi, R. (2014). Climate Change Mitigation Finance for Smallholder Agriculture: A guide book to harvesting soil carbon sequestration benefits FAO Rome http://www.fao.org/docrep/015/i2485e/ i2485e00.pdf.

[5] Xu L. and Marinova D., (2013). Resilience thinking: a bibliometric analysis of socio-ecological research ", Scientometrics, vol., p.DOI 10.1007/s11192- 11013-1095711190 .

[6] Caves R. (2013). A simplified approach to stakeholder engagement in natural resource management: the Five-Feature Framework: Ecology and Society, vol. 21, no. 4, 2016. JSTOR, JSTOR, www.jstor.org/stable/26270020.

[7] Butler H and Adamowski J. (2015). Towards adaptive and integrated management paradigms to meet the challenges of water governance; water science and technology : a journal of the International Association on Water Pollution Research, T1 - Towards adaptive and integrated management paradigms to meet the challenges of water governance, $\mathrm{VL}-6$.

[8] Turner M. D., 2014, « Political ecology I: An alliance with resilience?», Progress in Human Geography, vol. $38, \mathrm{n}^{\circ} 4$, p.616-623.

[9] Jensen, N., M. Ikegami, and A. Mude. 2016. "Integrating social protection strategies for improved impact: A comparative evaluation of cash transfers and index insurance in Kenya." Unpublished.

[10] Talley, J. L., J. Schneider, and E. Lindquist. 2016. A simplified approach to stakeholder engagement. In natural resource management: the Five-Feature Framework. Ecology and Society 21(4): 38. https://doi.org/10.5751/ES-08830210438.

[11] Delia C. \& Joseph T (2015). Engaging Stakeholders in Integrated Natural Resource Management: approaches and guidelines from Land care, New Delhi
[12] De Leeuw, J. (2016). Trees and Watershed Management in Karamoja, Uganda: Evidence on Demand. Climate \& Environment, Infrastructure and Livelihoods. A quick desk study commissioned by DFID Uganda.

[13] Mutekanga, F. P., Kessler, A., Leber, K., \& Visser, S. (2013). The Use of Stakeholder Analysis in Integrated Watershed Management: Experiences From the Ngenge Watershed, Uganda. Mountain Research and Development, 33(2), 122-131.

[14] Kyarigonza R (2014). Correlates of Research utilization in Institutions of Higher LEraning, Unpublished MA dissertation submitted to Makerere University.

[15] Mugenda, O. (2003). Mugenda (1999). Research methods: Quantitative and qualitative approaches.

[16] The National Climate Change Policy (NCCP, 2012), Kampala, Uganda

[17] Tabachnick H and Fidell J, (2007). Application of data screening Procedures, Vol. 5, No. 2. Copyright. The New School for Social Research

[18] Marshall, G. (1998). Snowballing technique. A dictionary of sociology, 201-216.

[19] Andersson, K. P., \&Ostrom, E. (2008). Analyzing decentralized resource regimes from a polycentric perspective. Policy sciences, 41(1), 71-93.

[20] Akello, S., Turyahabwe, N., Sseguya, H., Okullo, P., \&Agea, J. G. (2017). Local community participation in restoration of watersheds in Uganda.

[21] Sikor, T., \& Lund, C. (2009). Access and property: a question of power and authority. Development and change, 40(1), 1-22.

[22] Ong'or, D.O. (2005). Community participation in Integrate Water Resource Management: The case of the lake Victoria Basin. Kenya: Department of Agriculture.

[23] Agrawal, A., \& Gupta, K. (2005). Decentralization and participation: the governance of common pool resources in Nepal's Terai. World development, 33(7), 1101-1114.

[24] Few, R. (2003). Flooding, vulnerability and coping strategies: local responses to a global threat. Progress in Development Studies, 3(1), 43-58.

[25] Baltissen, G., \& Betsema, G. (2013). Linking land governance and food security in Africa.

[26] Holling C. S. (2015) Foundations of Ecological Resilience, Washington, Island Press.

[27] Mulugeta L (2004). Effects of land use change on soil quality and native flora degradation and restoration in the highlands of Ethiopia. Implication for sustainable land management. Ph.D Thesis. Swedish university of Agricultural Science. Uppsala, Sweden.

[28] Tippett, J., Searle, B., Pahl-Wostl, C., \& Rees, Y. (2005). Social learning in public participation in river basin management - early findings from HarmoniCOP European case studies. Environmental science \& policy, 8(3), 287-299. 